\title{
Two species of Amaryllidaceae, new distributional record for Tripura, North East India.
}

Dipan Sarma and Bimal Debnath*

Plant Diversity and Forest Biotechnology Laboratory, Department of Forestry and Biodiversity, Tripura

University, Suryamaninagar-799022, Tripura, Northeast India.

Received: July 10, 2016; Accepted: July 18, 2016.

\begin{abstract}
The present studies provided the new distribution record of two species, Hymenocallis littoralis and Crinum latifolium of Amaryllidaceae from Tripura. These species, so far have not been recorded previously from Tripura. Both the species have ethnomedicinal usages. The plants were collected, identified with the help of various flora and available database. This communication highlighted brief description, proper citation, medicinal uses, distribution pattern, phenological observation, and photographs of the species.
\end{abstract}

Key words: Amaryllidaceae; New records; Tripura; Ethno-medicinal usage.

\section{Introduction}

Tripura, foot Himalayan state of North-East India is well known for its rich floral and faunal diversity. It is situated in between $22^{\circ} 56^{\prime} \mathrm{N}$ to $24^{\circ}$ $32^{\prime} \mathrm{N}$ latitude and $90^{\circ} 09^{\prime} \mathrm{E}$ to $92^{\circ} 20^{\prime} \mathrm{E}$ longitude with a forest cover about $60 \%$ out of the 10497.69 sq. $\mathrm{km}$ of the total land area of the state. The average annual rainfall of the state ranges from $1700 \mathrm{~mm}$ to $2100 \mathrm{~mm}$ and temperature varies from $7^{\circ}-37^{\circ} \mathrm{C}$. Physiographically the state is hilly terrain with distinct five hill ranges running parallel to each other from North-South, which supports lavish growth of plant diversity. About $86 \%$ of the species occurring in the state are widely distributed in India and neighboring countries. The remaining $14 \%$ plant species are comparatively restricted in distribution in Tripura (Deb, 1983). Now, the extensive field survey is conducted throughout the state to prepare a medicinal plant database of the state. During our survey throughout the state and consultation with the relevant literature it was observed that so far two species namely, Hymenocallis littoralis (Jacq.) Salisb. and Crinum latifolium L. of Amaryllidaceae have not been reported from Tripura. Therefore, the present study clearly indicates the new addition of these species to the flora of Tripura.

The family Amaryllidaceae includes more than 75 genera and about 1100 species in which the genus Hymenocallis contains about 70 species (Zhong 2013). Only one species, Hymenocallis littoralis was reported from Southern part of India by BSI, but its distribution in Tripura was missing. Hymenocallis is distributed throughout the state in Tripura as both as ornamental and in wild state.

Crinum is one of the largest genera in the family Amaryllidaceae, represented by 113 species, 2 subspecies and 4 varieties in the world (Govaerts,

\section{*Corresponding Author:}

Dr. Bimal Debnath,

Assistant Professor,

Department of Forestry and Biodiversity,

Tripura University, Suryamaninagar - 799022,

Agartala, Tripura, India.

E-mail: bimalbc@,rediffmail.com
2014). The genus Crinum is represented by 15 species in India, of which 4 are endemic to Western Ghats, viz. C. brachynema Herb., C. malabaricum Lekhak \& S.R. Yadav, C. wattii Baker, C. woodrowii Baker ex W. Watson. (Yadav, 1997; Gaikwad \& Yadav, 2004). But in Tripura only two species viz. C. defixum Ker Gawl. and C. pretense Herb. were documented under the family Amaryllidiaceae by D. B. Deb, (1983). The presence of $C$. latifolium has not mentioned so far.

\section{Methodology}

The intensive survey was done on the distribution, population status, ecology and their use of medicinal flora in the state of Tripura. The voucher specimens were collected and standard taxonomic methods have been used for drying, and further processing of the specimens (Jain \& Rao, 1977) for the preparation of the herbarium sheets, which were deposited in the Department of Forestry and Biodiversity, Tripura University with a proper voucher specimen number for the preparation of medicinal database of the state. The fresh plant specimens have been identified using regional flora (D. B. Deb, 1981 \& 1983) and other published research works, relevant online e-flora (eFlora of China), Flora of Telangana (Pullaiah, 2015).

Hymenocallis littoralis (Jacq.) Salisb.: Terrestrial, upright, perennial herbs with underground large onion like bulbs, often rhizomes, about 1-1.5 m high. Leaves fleshy, basal rosette, simple, linear- lanceolate, entire, venation parallel, 6-12 cm wide and $25-70 \mathrm{~cm}$ long, erect or arching, distantly spreading, bright green, deciduous, apex acute. Inflorescence umbellate cymes, bracteate, subtended by spathe-like bracts, inflorescence borne on a leaf less long scape, scape

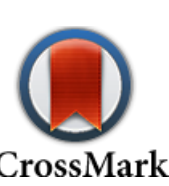


green, ribbed, two ridges. Flowers 21-25 per inflorescence, sessile, sequentially opening; perianth tube green, about $8-10 \mathrm{~cm}$ long, actinomorphic, bisexual, hypogynous, slightly diverging, large, perianth adnate basally into long tube, surrounded by funnel shape staminal corona, mouth of corona about $3 \mathrm{~cm}$ wide, tepals 6 , petaloid, tepals linear, about $10 \mathrm{~cm}$ long, extending from base of corona, free portion reflexed or ascending, imbricate. Stamen 6, basally connate into the funnel form corona, filaments long about $5 \mathrm{~cm}$, filament base inserted on corona margin, filaments base white and apex greenish, filaments erect- slightly incurved, filiform, anthers long, about 2-2.5 cm long, 2 celled, versatile, introse, vertical dehiscing, pollen yellow- orange. Ovary inferior, carpel 3, syncarpous, 3 chambered ovaries with 2 ovules in each chamber, placentation axile, style about $20 \mathrm{~cm}$ long, exerted, laterally deflexed, filiform, stigma 1, capitate.

\section{Synonym:}

Pancratium littorale Jacq.;

Pancratium littorale Jacq.;
Hymenocallis tenuiflora Herbert, Hymenocallis adnata Herb.; Pancratium staplesii (Sweet)Steud.; Troxistemon littorale (Jacq.) Raf.

Availability status: Locally available Locality: Throughout the state

GPS location of collected place: Suryamaninagar (2345'47.17" N; 91¹6'09.37" E).

Altitude: $83 \mathrm{ft}$.

Exsiccate: Suryamaninagar, Dipan Sarma, C.S.128; dated 28. 04. 2016.

Ecology: It grown in the road side dry and damp or moist area, cultivated as an ornamental plant for its pleasant flowers.

Phenology: Flowering and fruiting is March-July.

Distribution: Origin from Central America and Southern Mexico and reported to Argentina, Brazil, China, Colombia, French, Guinea, Liberia, Mexico, Peru, South India, United States.

Uses: The plant is ornamental. The plant is frequently cultivated in the garden. Bulbs paste is used for the treatment of wounds.

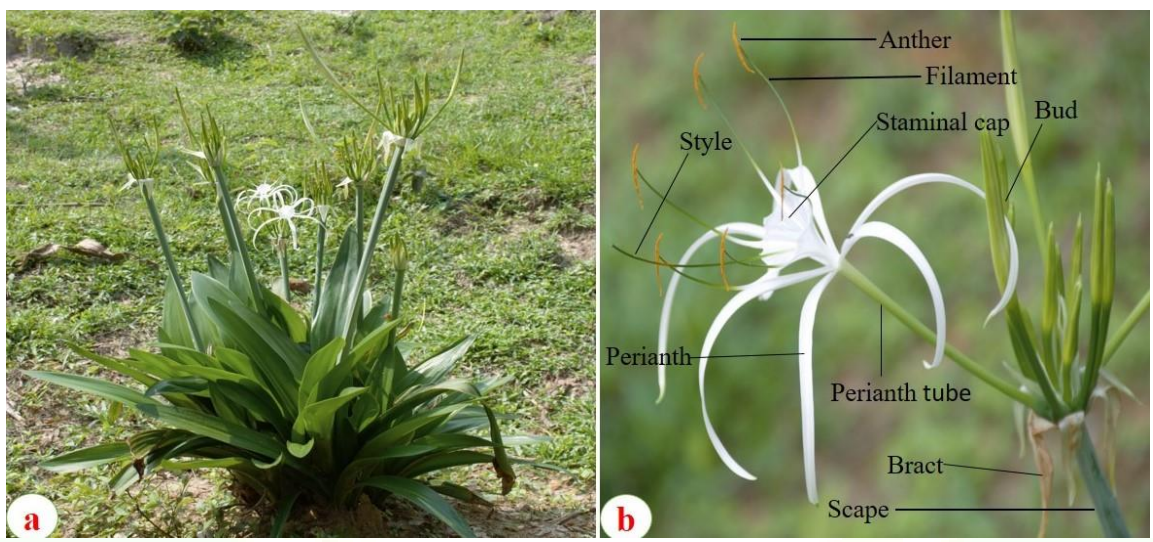

Plate 1: Hymenocallis littoralis (Jacq.) Salisb.: a- Habitat; b-: Different floral parts

Crinum latifolium L.: Terrestrial, perennial, a stout herb, with large tunicate bulbs, stoloniferous, ovoid, rosette like, clothed with old leaf sheath. Leaves simple, fleshy, coriaceous, smooth, entire margin, linear-lanceolate, about $45-100 \mathrm{~cm}$ long, wide about 3-6 cm, equally disposed, concave, parallel venation, apex acute. Inflorescence in umbellate cymes, subtended by large spathe-like bracts, inflorescence borne on a leaf less long scape, scape green, smooth, ribbed, two ridges. Spathe 2, pink coloured, triangular, smooth, coriaceous, apex shortly acute or obtuse, about $7 \times 5$ $\mathrm{cm}$, over lapped at base. Flowers 10-14 per inflorescence, with linear bracts, sessile, sequentially opening; actinomorphic, bisexual, hypogynous, slightly diverging, large, fragnant. Bracts linear, apex obtuse, pale red, about $4-6 \mathrm{~cm}$ long. Perianth adnate basally into long tube, salver shaped, tepals 6 , petaloid, tepals linear- lanceolate, about 10x $2 \mathrm{~cm}$, corona absent, apex mucronateapiculate, outer side of tepal pink, inner side pinkish white, imbricate; perianth tube pale reddish, cylindrical, about $10 \mathrm{~cm}$ long, pink coloured. Stamen 6, basally connate into the perianth throat, filaments long about $7 \mathrm{~cm}$, filaments base white and apex reddish, filiform, anthers long, about 2-2.5 cm long, 2 celled, black coloured, versatile, vertical dehiscing, pollen yellow. Ovary inferior, carpel 3, syncarpous, 3 chambered ovary with 2 ovules in each chamber, placentation axile, style about $20 \mathrm{~cm}$ long, pink coloured, exerted, filiform, stigma 1, capitate.

Synonym: Amaryllis insignis Ker Gawl; Crinum esquirolii H. Lev.; Crinum jemenicum Dammann; Crinum cochinchinense M. Roem.

Availability status: Locally rare, probably endangered in Tripura.

Locality: Brajendranagar, Udaipur.

GPS location of collected place: Brajendranagar (2334'13.87" N; 91³3'56.12" E).

Altitude: $156 \mathrm{ft}$. 
Exsiccate: Brajendranagar, Udaipur, Dipan Sarma, C.S.130; dated 16. 05. 2016.

Ecology: The plant is grown in the damp, forest covered area.

Phenology: Flowering and fruiting is May- July.

Distribution: Asia-Temperate China, China South Central China, Tropical Asia; Bangladesh, Sri
Lanka, Indo-China, Andaman Island, Myanmar, Nicobar Island, Thailand, Vietnam, India (Assam, Kerala).

Uses: Leaves are used for the treatment of tumor, piles and fistula and earache. Tribal traditional healers believe $C$. latifolium extend life span.
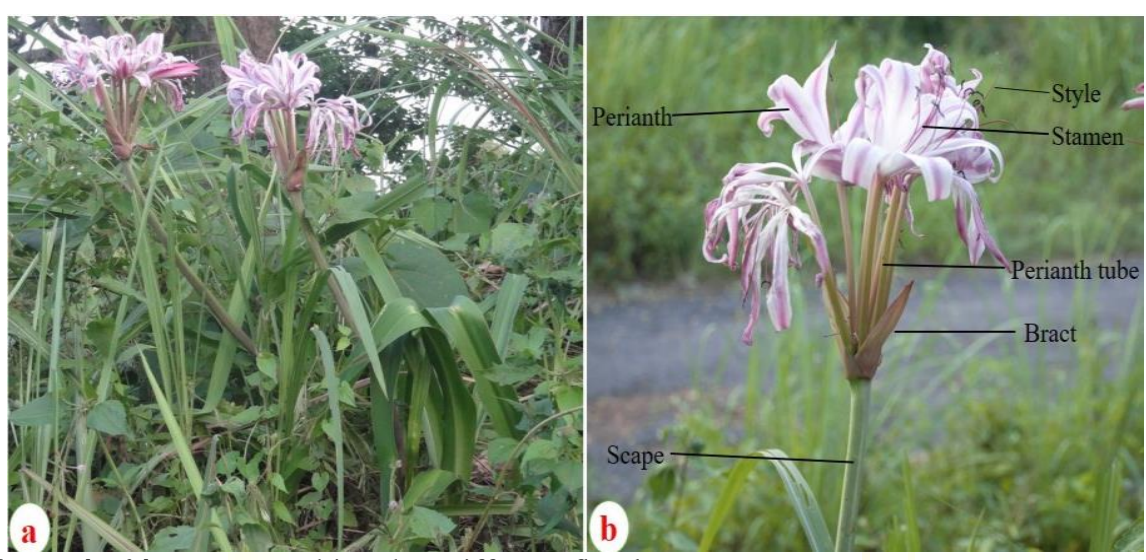

Plate 2: Crinum latifolium L.: a- Habitat; b-: Different floral parts

\section{Acknowledgement}

The authors are gratitude to CSIR for providing a grant [Sanction letter No. 38(1371)/13/EMR-II] which helped us to carry out this work. We are also thankful to Mr. Chiranjit Paul and Mr. Amal Debnath, Research scholar, Department of Forestry and Biodiversity, Tripura University for their unconditional support in our work.

\section{References}

1. Govaerts R, World Checklist of Amaryllidaceae. Facilitated by the Royal Botanic Gardens, Kew. Published on the Internet: http://apps.kew.org/wcsp/. Accessed on 03.04.2014.

2. Yadav SR, Endemic plants of Peninsular India with special reference to Maharashtra. In: Pokle DS, Kanir SP, Naik VN (eds.), Proceedings, VIILAAT Annual Meet and National Conference. Aurangabad, 1997, 31-51.

3. Gaikwad SP, Yadav SR, Endemic flowering plant species of Maharashtra and their possible utilization. In: Pullaiah T (ed.), Biodiversity in India, Regency Publications, New Delhi, 2004, 3, 50.
4. Zhong J, Amaryllidaceae and sceletium alkaloids, Nat Prod Rep., 2013, 30, 849-868.

5. eFlora of China, www.efloras.org

6. Deb DB, The Flora of Tripura State, New Delhi, Today \& Tomorrow's Printers and Publishers, 2, 1983.

7. Deb DB, The Flora of Tripura State, New Delhi, Todays \& Tomorrow's Printers and Publishers, 1, 1981.

8. Pullaiah T, Flora of Telangana, the $29^{\text {th }}$ state of India. New Delhi, Regency Publication, 3, 2015.

9. Jain SK, Rao RR, A hand book for field and herbarium methods, Today and tomorrow's printers and publishers, New Delhi, 1977.

\section{Cite this article as:}

Dipan Sarma and Bimal Debnath. Two species of Amaryllidaceae, new distributional record for Tripura, North East India. Annals of Plant Sciences 5.6 (2016): 1360-1362.

DOI: http://dx.doi.org/10.21746/aps.2016.06.003

Source of support: CSIR, New Delhi, India.

Conflict of interest: None Declared 